\title{
A Nearshore Wave and Current Operational Forecasting System
}

Author(s) :Amaya Alvarez-Ellacuria, Alejandro Orfila, Maitane Olabarrieta, Raul Medina, Guillermo Vizoso, and Joaquin Tintoré

Source: Journal of Coastal Research, Number 263:503-509. 2010.

Published By: Coastal Education and Research Foundation

DOI: http://dx.doi.org/10.2112/08-1133.1

URL: http://www.bioone.org/doi/full/10.2112/08-1133.1

BioOne (www.bioone.org) is a nonprofit, online aggregation of core research in the biological, ecological, and environmental sciences. BioOne provides a sustainable online platform for over 170 journals and books published by nonprofit societies, associations, museums, institutions, and presses.

Your use of this PDF, the BioOne Web site, and all posted and associated content indicates your acceptance of BioOne's Terms of Use, available at www.bioone.org/page/terms_of_use.

Usage of BioOne content is strictly limited to personal, educational, and non-commercial use. Commercial inquiries or rights and permissions requests should be directed to the individual publisher as copyright holder. 


\title{
A Nearshore Wave and Current Operational Forecasting System
}

\author{
Amaya Alvarez-Ellacuria ${ }^{\dagger}$, Alejandro Orfila ${ }^{\dagger}$, Maitane Olabarrieta ${ }^{\ddagger}$, Raul Medina ${ }^{\ddagger}$, \\ Guillermo Vizoso ${ }^{\dagger}$, and Joaquin Tintoré ${ }^{\dagger}$
}

Instituto Mediterraneo de Estudios

Avanzados (CSIC-UIB)

07190 Esporles, Spain

a.orfila@uib.es

\author{
*Environmental Hydraulic Institute \\ IH Cantabria \\ Universidad de Cantabria \\ 39005 Santander, Spain
}

\begin{abstract}
ALVAREZ-ELlaCURIA, A.; ORFILA, A.; OLABARRIETA, M.; MEDINA, R.; VIZOSO, G., and TINTORÉ, J., 2010. A nearshore wave and current operational forecasting system. Journal of Coastal Research, 26(3), 503-509. West Palm Beach (Florida), ISSN 0749-0208.

An operational forecasting system for nearshore waves and wave-induced currents is presented. The forecasting system (FS) has been built to provide real time information about nearshore conditions for beach safety purposes. The system has been built in a modular way with four different autonomous submodels providing, twice a day, a 36-hour wave and current forecast, with a temporal resolution of 1 hour. Making use of a mild slope parabolic model, the system propagates hourly deep water wave spectra to the shore. The resulting radiation stresses are introduced in a depth-integrated Navier-Stokes model to derive the resulting current fields. The system has been implemented in a beach located in the northeastern part of Mallorca Island (western Mediterranean), characterized by its high touristic pressure during summer season. The FS has been running for 3 years and is a valuable tool for local authorities for beach safety management.
\end{abstract}

ADITIONAL INDEX WORDS: Rip currents, wave propagation, surf zone currents generation, beach hazards.

\section{INTRODUCTION}

Coastal areas are among the most complex and variable marine systems because their dynamics are subjected to the effects derived from a complex geometry, where the bathymetry plays a crucial role in wave propagation. Moreover, the wide range of processes affecting coastal hydromorphodynamics such as waves, currents, and tides, among others, interact at different spatial and temporal scales, making these zones highly variable environments.

Despite the socioeconomical relevance of coastal areas, modeling, observation, and continuous monitoring of coastal variability is to date scarce because of the intrinsic complexity of these systems. Besides the morphological importance of coastal areas, they are a major recreational resource around the world, and human activities have been constantly growing in the last three decades. Coastal management has increasingly relied on the scientific results obtained from different research fields that have been transferred to new engineering methodologies and applications to environmental systems in search of new, more integrated, and sustainable solutions to coastal problems. Although beach erosion and coastal evolution are, in a global change context, top scientific issues, accurate information, in an operational sense, of short term variability is still required by governments and end users.

Continuous observation of coastal variability is expensive

DOI: 10.2112/08-1133.1 received 19 September 2008; accepted in revision 29 January 2009. and sometimes impossible to obtain. Comprehensive information in coastal areas is nowadays required to establish efficient coastal zone monitoring as well as to develop management policies to effectively study these marine systems (Smit et al., 2007). The scarcity, and in most cases the lack, of information becomes a problem when scientists need to assess the current state (diagnostic) of specific coastal systems as well as to build predictive models (prognostic) of their evolution. The spatial and temporal evolution of different physical systems can be expressed in terms of differential equations. However, the numerical resolution of the aforementioned equations needs data to establish the systems' initial conditions. Moreover, because of their nonlinear nature, continuous data update is required to correct the deviations of the numerical predictions from the real state.

Experiments to provide a complete overview of nearshore dynamics have been shown to be the most useful tool to improve the understanding of short term variations of coastal dynamics (Herbers et al., 2003; Reiners et al., 2004). Unfortunately maintaining such experiments, which is required in any operational activity, is logistically and economically difficult. Only recently, with the development of new observing technologies, has it been possible to provide observations in a continuous way of some aspects of nearshore variability on all relevant time scales (Davidson et al., 2007). Besides, as a result of the increasing capacity of computers nowadays, only a short computational time is required to solve complex numerical models. This has made possible the development of operational systems for deep water wave conditions and cur- 

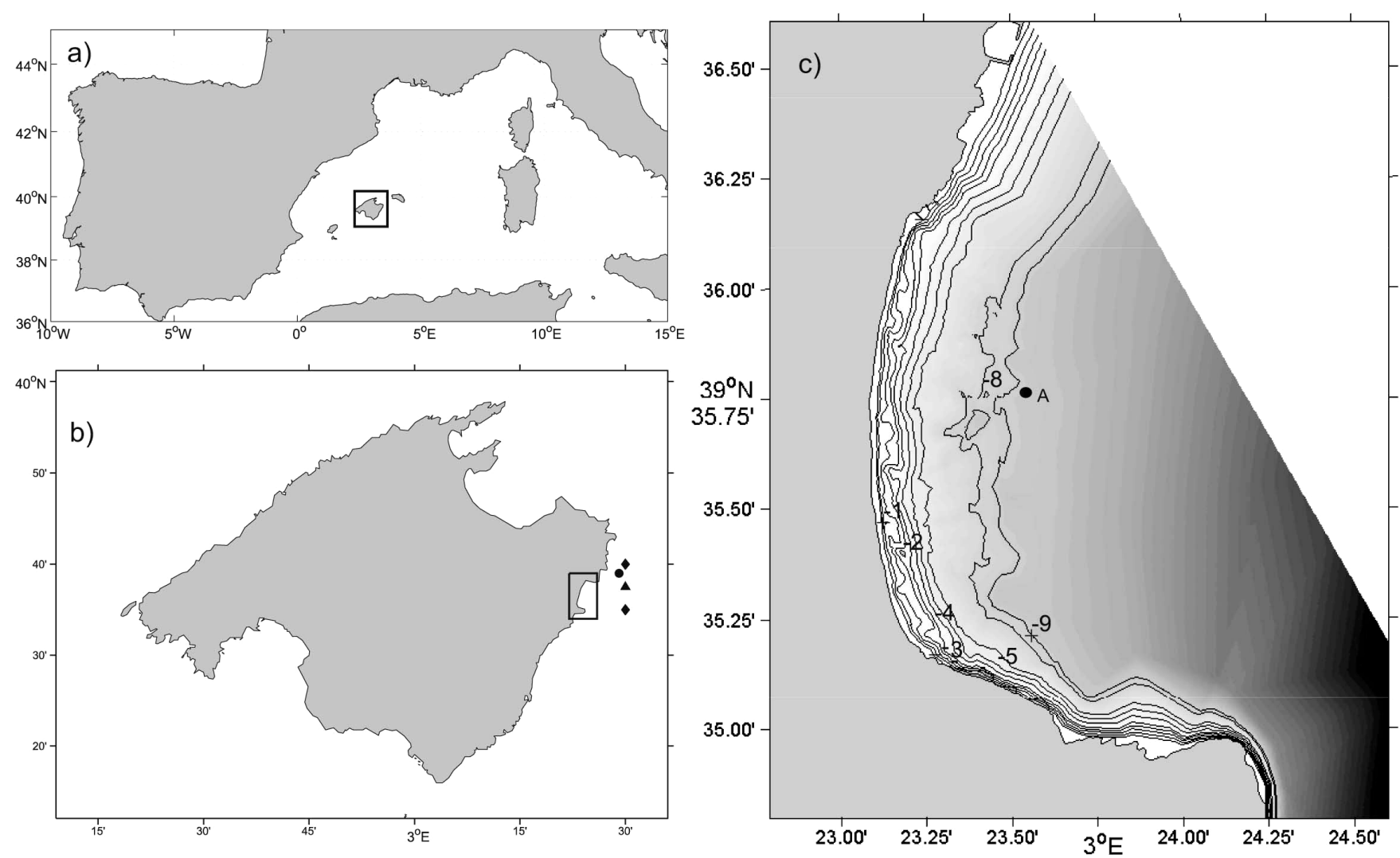

Figure 1. (a) Geographic location of the pilot area: Mallorca Island is inside the frame. (b) Mallorca Island: symbols in this panel correspond to deep water wave buoy (circle), Hipocas node (triangle), and the deep water WAM prediction points (diamonds). (c) Cala Millor beach: Point A indicates location of the acoustic current meter moored during the February 28, 2006-March 8, 2006 experiment.

rents, which are presently available (Bidlot et al., 2002; Hodur, 1997). However, because waves are the driving mechanism for littoral dynamics, not only is accurate deep water wave characterization crucial but water wave propagation from deep to shallow water also needs to be solved in an efficient way. Because water waves propagate from the region where they were generated to the coast, both wave amplitude and wavelength are modified because of refraction (e.g., changes in the bathymetry or interactions with wind induced currents), diffraction (e.g., intense variations of the bottom), and energy changes due to shoaling, damping, and finally wave breaking (Liu and Losada, 2002). The surf zone is a highly dynamic area where wave energy is partially dissipated through turbulence and transformed in short and long waves, mean sea level variations, and currents. Therefore energy dissipated in the surf zone is used for sediment transport, providing a highly variable morphological environment (Dean and Dalrymple, 2002). Breaking waves generate narrow currents sometimes directed seaward through the surf zone because of an excess of momentum flux (Bowen, 1969). These "rip" currents are identified as being responsible of more than 100 deaths annually in the United States (see for instance NOAA, 2008). Nowadays several model packages are commercially available to study the hydrodynamic and morphodynamic processes in coastal areas, e.g., DELF3D, SMS, or MIKE21. The application of new insights in nearshore hydrodynamics for public safety issues is nowadays becoming more frequent. Recently, Conley et al. (2008) presented a rapid environmental assessment providing hydrodynamic information in real time; Rusu, Conley, and Ferreira-Coelho (2008) and Allard et al. (2008) presented new nearshore forecasting systems. This information can be used by coastal managers.

In this article a new operational forecasting system (FS) developed to provide short term prediction of waves and currents is presented. The FS has been implemented in an intermediate barred beach in the western Mediterranean Sea (Figure 1a). This coastal area is well exposed to severe storms events mainly during late fall and winter, and is characterized by a strong occupancy during the summer season. Waves and currents are predicted twice a day with a 36-hour horizon. Atmospheric predictions are obtained automatically from the Spanish Meteorological Institute (INM) based on the forecasts produced with the High Resolution Limited Area Model (HIRLAM) model. The Spanish Harbour Authority (Puertos del Estado) force the Wave Model (WAM) Cycle4, with hourly wind fields. Deep water hourly spectra for the next 36 hours are propagated to the beach using a mild slope parabolic model (GIOC, 2003a; González et al., 2007). This model includes the effects of refraction and diffraction, as 
well as the shoaling and dissipation due to bottom friction and breaking (Kirby, 1986). The wind wave fields obtained from the parabolic model are finally introduced as the forcing terms in a two-dimensional depth-integrated Navier-Stokes model. The model is solved over the detailed beach topography, computing the radiation stress terms and deriving the currents induced by wave breaking and the possible oblique wave incidence (GIOC, 2003b; González et al., 2007). Following this methodology a wave and current forecast for the next 36 hours is generated and provided to users via the Internet. This procedure is repeated twice a day.

\section{STUDY AREA}

The aforementioned FS has been implemented in Cala Millor, located in the northeast coast of Mallorca Island (Figure 1b). The beach is in an open bay with an area of about 14 $\mathrm{km}^{2}$, extending to depths up to 20-25 m. From the coastline to the 8-m water depth contour, the bathymetry presents a regular slope indented with near shore sandbars that migrate from offshore to onshore during periods of mild wave conditions (Figure 1c). At depths from 8 to $35 \mathrm{~m}$ the seabed is covered by a Posidonia oceanica meadow, an endemic sea grass species of the Mediterranean Sea (Infantes et al., 2009). Cala Millor is a tourist resort with a population of 6072 permanent inhabitants. However, during the summer this number can increase up to 17,046 inhabitants. The tourist occupancy is between $74.6 \%$ and $91.3 \%$ of the hotel beds during summer season. This means that during the summer season the Cala Millor real population achieves the value of 20,263 inhabitants, three times more people than during the rest of the year. Daily mean number of beach users fluctuates from 6400 to 6800 ; at the end of the tourist season, these rates mean that at least 500,000 individuals have engaged in recreational activities at Cala Millor beach.

The tidal regime is microtidal with a spring range less than $0.25 \mathrm{~m}$ (Gomez-Pujol et al., 2007). According to the criteria of Wright and Short (1984), Cala Millor is an intermediate barred sandy beach formed by biogenic sediments with median grain values ranging between 0.28 and $0.38 \mathrm{~mm}$ at the beach front.

\section{Wave Climate}

Wave climate characterization has been performed using Hindcast of Dynamic Processes of the Ocean and Coastal Areas of Europe (HIPOCAS) data, consisting of hourly wave data from a 44-year wave hindcast (Soares et al., 2002). Hindcast models have become a powerful tool, not only for engineering or prediction scales but for climate purposes involving large temporal periods (Cañellas et al., 2007). For the study area, the virtual wave gauge is located $10 \mathrm{~km}$ offshore, at a water depth of $50 \mathrm{~m}$ (triangle in Figure 1b). The significant wave heights' long term probability distribution function (log normal), derived from the statistical analysis of the hindcasts data, shows that the significant wave heights $\left(H_{s}\right)$ exceed $1 \mathrm{~m} 50 \%$ of time. Moreover, the analyzed data show that the typical peak period $\left(T_{p}\right)$ in the study area is characterized by a value between 3 and 6 seconds. The annual and summer wave conditions are shown in Figure 2. The
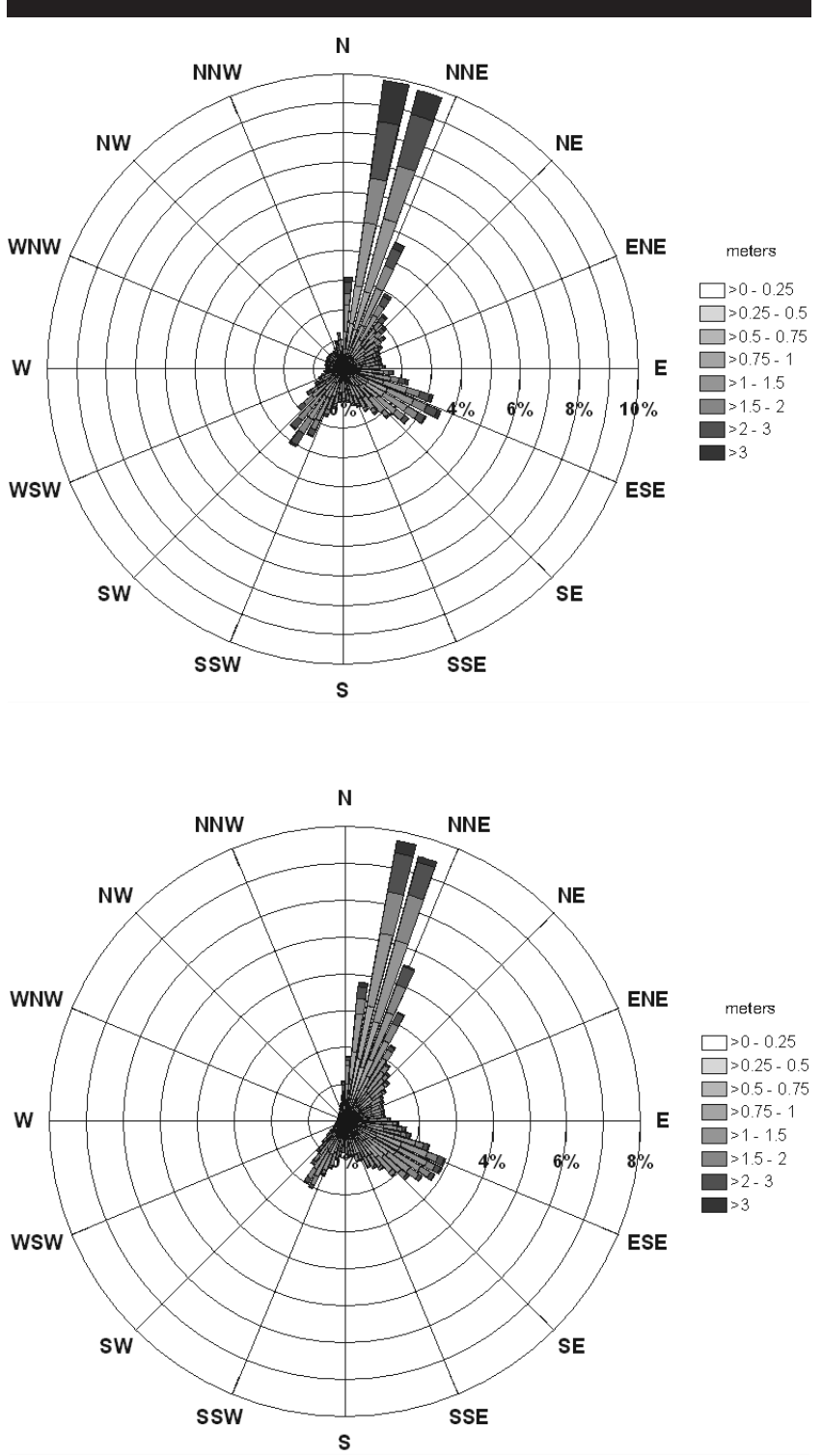

Figure 2. Annual wave regime (upon panel) and summer wave regime (bottom panel) for the deep water point (triangle in Figure 1b).

most energetic waves are usually from the north and northeast, which are the most common directions, with wave heights between $1-4 \mathrm{~m}$.

\section{DATA AND METHODOLOGY}

\section{Forecasting System}

The FS has been built in a modular way with four independent submodels (Figure 3). Hourly wind predictions are provided daily by the Agencia Estatal de Meteorología (AEMET, formerly INM) using the HIRLAM model (Unden et al., 2002) over a mesh of $0.2^{\circ}$ for the 24-hour horizon and over a mesh of $0.5^{\circ}$ after 1 day. Wind fields at $10 \mathrm{~m}$ height are used as the meteorological input for the WAM cycle 4 wave model on the oceanic scale (Gomez and Carretero, 1997). These pre- 
dictions are carried out operationally over the Mediterranean Sea by the Spanish Harbour Authority, and provide a 3-day forecast of wave height and wave direction. The deep water wave conditions at two different nodes located near the beach $\left(39^{\circ} 40^{\prime} \mathrm{N}, 3^{\circ} 30^{\prime} \mathrm{E}\right.$; $39^{\circ} 35^{\prime} \mathrm{N}, 3^{\circ} 30^{\prime} \mathrm{E}$ ) (see diamonds in Figure 1b) are propagated to Cala Millor beach using a mild slope model. To correctly simulate the propagation of waves coming from different directions, we implemented two different meshes with a resolution of $15 \mathrm{~m}$ in the area.

The wave propagation model solves the parabolic form of the mild slope equation (Kirby and Dalrymple, 1983),

$$
\begin{aligned}
& \frac{D^{2} \phi}{D t^{2}}+(\nabla \cdot \mathbf{U}) \frac{D \phi}{D t}-\nabla \cdot\left(C c_{g} \nabla \phi\right)+\left(\sigma^{2}-k^{2} C c_{g}\right) \phi \\
& +2 \sigma\left(\mathbf{k} \cdot \nabla \phi_{2}-\frac{k^{2}}{2 \sigma \cosh ^{2} k h}\right) \phi+\sigma^{2} k^{2} \delta|A|^{2} \phi \\
& \quad+i \sigma \frac{\gamma}{2} \phi=0,
\end{aligned}
$$

where $D$ is the total derivative, $\phi$ is the velocity potential at the free surface, $U$ is the current velocity, $\sigma$ is the frequency, $C$ is the wave celerity, $c_{g}$ is the group velocity, $\phi_{2}$ the long wave velocity potential, $\nabla$ is the nabla operator, $\mathbf{k}$ the wave number, $A$ the wave amplitude, $h$ the water depth, $\delta$ is a dissipation factor due to the bottom, and $\delta$ is part of the nonlinear term, expressed as:

$$
\delta=\frac{\cosh (4 k h)+8-2 \tanh ^{2}(k h)}{8 \sinh ^{4}(k h)} .
$$

The last term in Equation (1) accounts for the viscous effects due to the bottom. Wave breaking and bottom dissipation are parameterized using the breaking wave model bore, following Battjes and Janssen (1978). The bottom friction is based on the Darcy-Weisbach turbulent friction coefficient (Dean and Dalrymple, 1984).

The current model is based in the solution of the momentum and continuity averaged equations. The resulting radiation stresses obtained in the mild slope model are introduced into a depth-integrated Navier-Stokes movement equation, e.g.,

$$
\begin{aligned}
& \frac{D U_{i}}{D t}+g \frac{\partial \eta}{\partial x_{i}}+\frac{1}{\rho H} \frac{\partial}{\partial x_{i}}\left(S_{i i}\right)+\frac{1}{\rho H} \frac{\partial}{\partial x_{j}}\left(S_{i j}\right)+\frac{g U_{i}}{c^{2} H}\left(U_{i}^{2}+U_{j}^{2}\right)^{1 / 2} \\
& -\varepsilon\left(\frac{\partial^{2} U_{i}}{\partial x_{i}^{2}}+\frac{\partial^{2} U_{j}}{\partial x_{j}^{2}}\right)=0,
\end{aligned}
$$

where $U_{i}$ is the horizontal velocity $(u, v)$ in the $x_{i}$ direction $(x, y), \eta$ is the free surface elevation, $H$ is the total water depth, $c$ is the Chezy coefficient, $\varepsilon$ represents the eddy viscosity, and $S_{i j}$ represents the radiation stress terms.

\section{RESULTS AND DISCUSSION}

\section{Daily Forecasts}

Twice a day, wave energy spectra predictions at the two aforementioned deep water nodes are received. Depending on the wave direction, the system selects the most suitable node to process its information to fulfil the parabolic approxima-
HIRLAM MODEL

WIND PREDICTION

Input: wind fields

$10 \mathrm{~m}$ above the sea

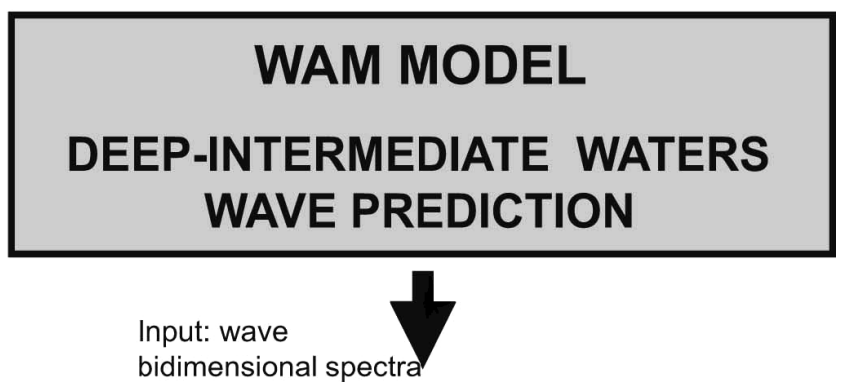

bidimensional spectra

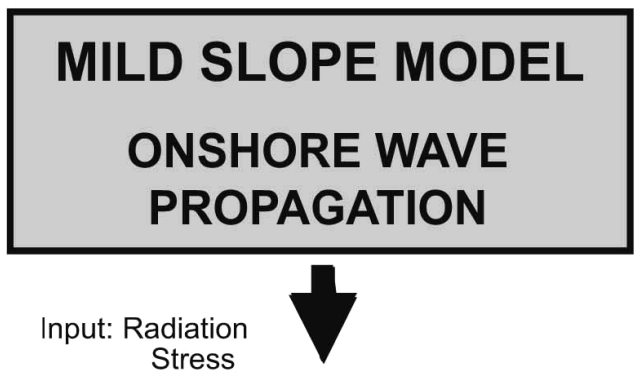

\section{DH NAVIER-STOKES MODEL \\ SURFZONE CURRENTS GENERATION}

Figure 3. Scheme of the different models used in the forecasting system.

tion. Two different meshes have been predefined for the two different prediction points with the seaward boundary at the same location of the corresponding points.

The FS system has been operational since April 2005, providing 36-hour horizon day forecast of the wave height, direction, and surf zone currents to the Search and Rescue authorities who are responsible for beach safety. Maps with beach condition information (waves and currents) are updated automatically via internal file transfer protocol (ftp) and used to manage the risk at the beach. In addition, wave conditions are stored for statistical purposes.

The highly variable environment with sandbars moving continuously onshore (offshore), depending on mild (storm) conditions, force us to perform bathymetric surveys every 2 months on average. New bathymetries are used to generate the new numerical meshes where models are run. This is a crucial point because bathymetry has to be updated at least 

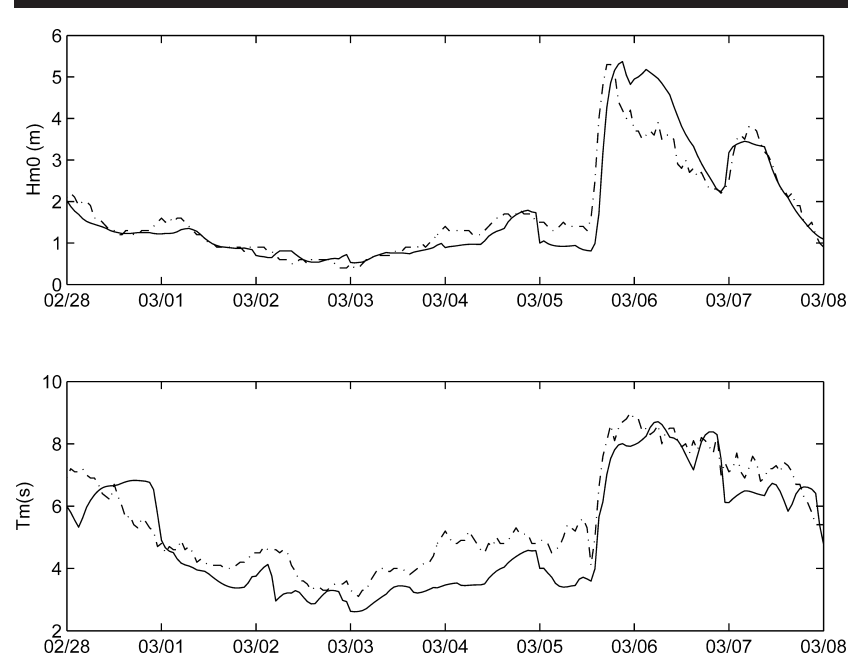

Figure 4. Significant wave height (top panel), and mean period (bottom panel) at $45 \mathrm{~m}$ depth. Solid lines correspond to the forecast and dashed lines to observations.

after every storm event to get the exact position of the sandbars and rip channels. Currently this is performed with a ship-mounted Biosonics DE-4000 echo sounder equipped with a $200-\mathrm{KHz}$ transducer. The draught of the boat allows sampling to depths of about $0.5 \mathrm{~m}$. Inshore-offshore and alongcoast echo sounding transects are sampled perpendicular to the bathymetric gradient with a separation of $50 \mathrm{~m}$ between transects. The acoustic pulse rate is set to $25 \mathrm{~s}^{-1}$, and the sampling speed was set to 3 knots, which allows for a horizontal resolution of $1 \mathrm{~m}$. This procedure provides accurate bottom mapping but is very time consuming.

\section{Validation}

To test the performance of the FS, we carried out a field experiment from February 28 to March 8, 2006. For this pe- riod, time series of wave height and wave period measured with a buoy located at $45 \mathrm{~m}$ depth (circle in Figure 1b) are compared with the time series of the predicted wave conditions (northern diamond in Figure 1b) provided by the Spanish Harbours Authority (Figure 4). The correlation between predicted and measured data for the significant wave height during 2005-2007 is around 86\% with a RMS of 0.37 ; for the mean period around $78 \%$ with a RMS of 1.32 , and for the mean direction $91 \%$ with a RMS of 0.56 .

During the experiment, an acoustic wave and current meter (AWAC), was moored at $10 \mathrm{~m}$ depth, approximately 700 $\mathrm{m}$ offshore (point A, Figure 1c). This instrument provided the incident wave height, period, and direction during the first 20 minutes of each hour, at a sample rate of $1 \mathrm{~Hz}$. Time series comparing measured significant wave height and that predicted by the system are shown in Figure 5. As seen, on March 6th a storm over the area generated significant wave heights, up to $1.5 \mathrm{~m}$ and maximum peak periods of $10 \mathrm{sec}-$ onds, which are reasonably well predicted by the system. During the period marked in gray there were no available forecasting data because the incoming waves were from the southwest. Although the predictions are well correlated with observations (78.4\% of agreement), the observed discrepancies could be related with WAM period predictions, which do not correlate exactly with the buoy data during the first 5 days of March and with the fact that local winds (sea breezes) are not included in the system. Additionally, a current meter was moored at a water depth of $1.5 \mathrm{~m}$ to capture the mean velocities every minute. However, measured currents did not show any indication of seaward outgoing water. During the first 3 days of the experiment, the difference between the direction of measured currents and the predicted ones is less than $13 \%$. Unfortunately during the storm event, the current meter was buried and therefore there are no current data available for this period.

To have an overall view of the current system in Cala Millor beach, the Spanish Air Force performed a photographic

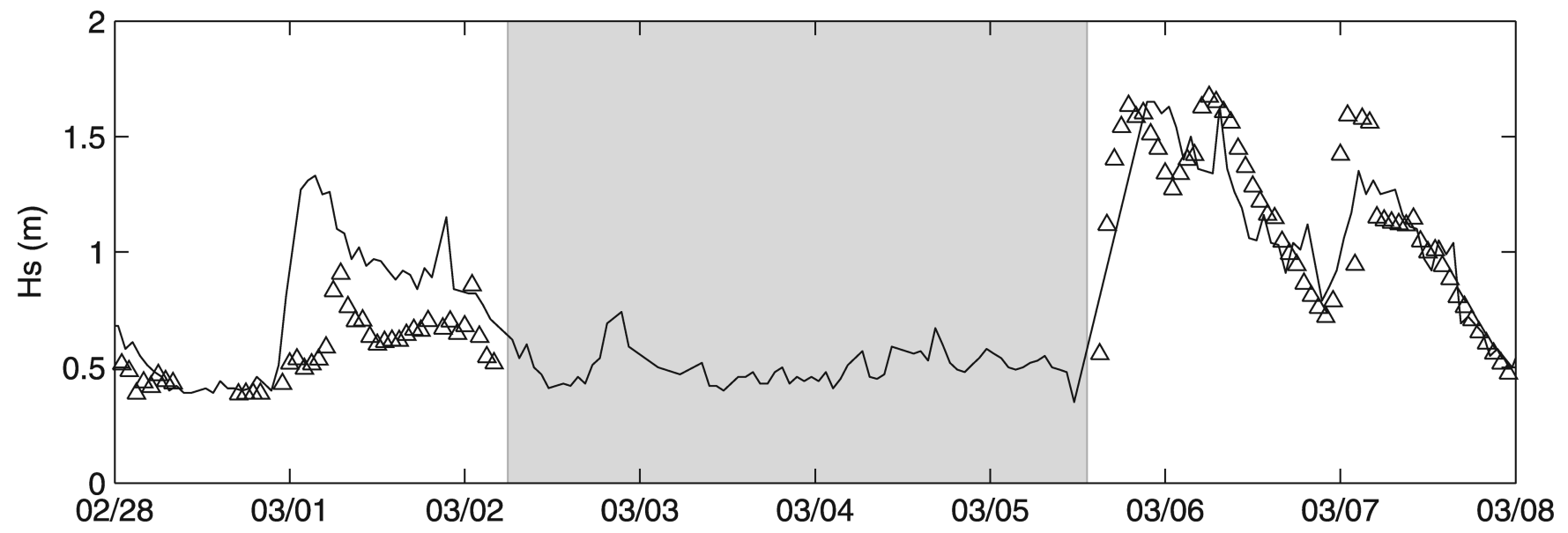

Figure 5. Significant wave height at $10 \mathrm{~m}$ (location A in Figure 1c) during the field experiment. Solid line corresponds to measurements and triangles to the hourly prediction provided by the FS. During the period marked in gray there were no available forecasting data because incoming waves were from the southwest. 


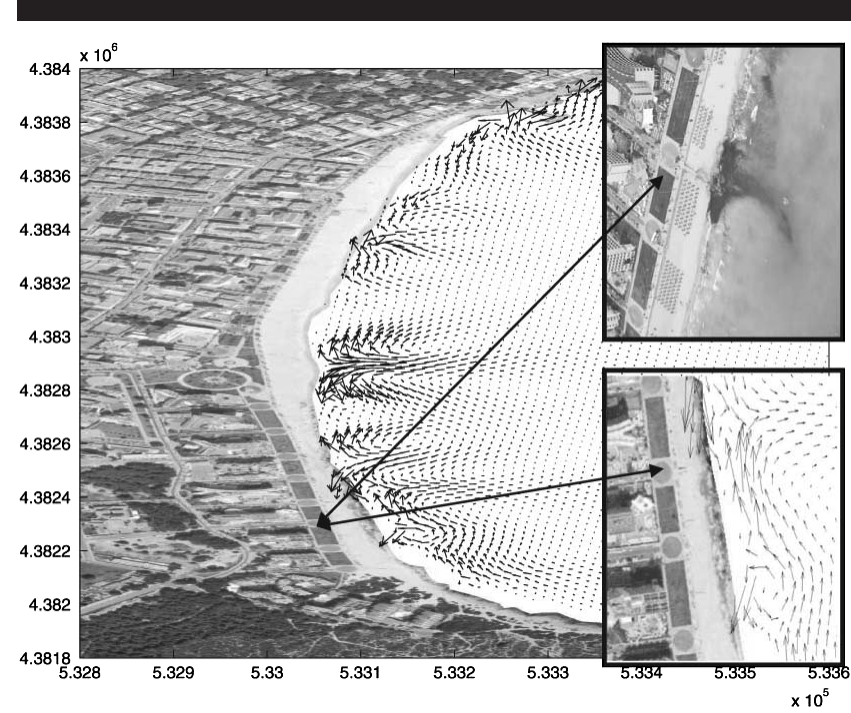

Figure 6. Current field for May 30, 2005, at 18:00. The aerial photography at that time is represented at the upper-right side of the picture, while the predicted rip current is represented in the bottom-right side. The location of the predicted rip-current coincides with the area in which $P$. oceanica leaves are present.

survey all over the beach. This kind of data is very useful because it provides visual signals of surf zone currents. Figure 6 shows the aerial photography of May 30, 2005 (upper right), where the accumulated leaves of the endemic species $P$. oceanica serves as a passive tracer for the identification of the wave-induced currents. Rip location can be visually identified by a line of foam, seaweed, or debris moving steadily seaward (Komar, 1998). In the same picture the predicted currents of the same day over the whole study area are shown. Comparing the aerial photography with the forecasted current field indicates that the system is able to predict the outgoing flows. This visual estimation of a rip current is made by several lifeguard associations as well as by the National Oceanic and Atmospheric Administration (NOAA), whose Web site explains how to identify rip currents where "a line of foam, seaweed, or debris moving steadily seaward."

\section{CONCLUSIONS}

In this article we have presented an operational forecasting system for the prediction of waves and breaking currents in shallow waters. Nearshore waves are obtained by the propagation of deep water conditions to the area. Breaking currents are obtained after the inclusions of the radiation stresses in a depth-integrated Navier-Stokes model. The FS has been working for 3 years, providing the nearshore hydrodynamics in an autonomous and operational way. Some interruptions occurred during this period, mainly due to problems related with connections between the local server and the server located in the Spanish Harbours Authority. Information of wave height and wave induced currents in the beach are automatically generated by a Web server that can be checked by the lifeguards immediately using a pocket PC to improve beach safety.
Field experiments were carried out to test the forecasting capabilities of the system showing that predictions of wave height and direction are well correlated with observations. Directions of currents in the surf zone are also well predicted. Wave breaking currents were qualitatively validated using aerial photography because they were not measured during the field experiments.

Although the FS developed seems to be a useful tool to obtain estimations of the occurrence, location, and intensity of wave breaking currents, several improvements have to be implemented. First, because accurate bathymetry is continuously required, it is necessary to develop low cost techniques to obtain bathymetry. In this sense, matching video-based techniques with the presented approach have to be explored. The inclusion of local wind forcing, such as the sea breeze, would also improve the input wave conditions at the outer boundary of the beach. Future research also is directed to the inclusion of other physical mechanisms generating rip currents through Boussinesq-type models.

\section{ACKNOWLEDGMENTS}

The authors would like to thank the Dirección General de Emergencias of the Balearic Islands Government and MICINN (CTM2006-12072) for financial support We are also indebted to the Esquadron 801 Search and Rescue of the Spanish Air Force for the photographic surveys. We gratefully also thank the Area del Medio Físico of the Spanish Harbours Authority for the deep water data.

\section{LITERATURE CITED}

Allard, R.; Dykes, J.; Hsu, Y.L.; Kaihatu, J., and Conley, D. A realtime nearshore wave and current prediction system. Journal of Marine Systems, 69(1-2), 37-58.

Battjes, J.A. and Janssen, J.P.F.M., 1978. Energy loss and set-up due to breaking of random waves. In: Proceedings of 14th International Conference on Coastal Engineering (Hamburg, Germany, ASCE), pp. 466-480.

Bidlot, J.R.; Holmes, D.J.; Wittmann, P.A.; Lalbeharry, R., and Chen, H.S., 2002. Intercomparison of the performance of operational ocean wave forecasting systems with buoy data. Weather and Forecasting, 17, 287-310.

Bowen, A.J., 1969. Rip currents, 1, theoretical investigations. Journal of Geophysical Research, 74(23), 5467-5478.

Cañellas, B.; Orfila, A.; Méndez, F.J.; Menéndez, M., and Tintoré, J., 2007. Application of a POT model to estimate the extreme significant wave height levels around the Balearic Sea (Western Mediterranean). Journal of Coastal Research, Special Issue No. 50, pp. 329-333. Proceedings of the 9th International Coastal Symposium.

Conley, D.; Trangeled, A.; Zappa, G.; Gualdesi, L.; Guerrini, P., and Holman, R.A. 2008. Rapid environmental assessment in the nearshore. Journal of Marine Systems, 69(1-2), 59-73.

Davidson, M.; Van Koningsveld, M.; De Kruif, A.; Rawson, J.; Holman, R.; Lamberti, A.; Medina, R.; Kroon, A., and Aarnikhof, S., 2007. The CoastView Project: developing video-derived coastal state indicators in support of coastal zone management. Coastal Engineering, 54, 463-475.

Dean, R.G. and Dalrymple, R.A., 1984. Water Wave Mechanics for Engineers and Scientists. Englewood Cliffs, New Jersey: PrenticeHall, 353p.

Dean, R.G. and Dalrymple, R.A., 2002. Coastal Processes with Engineering Applications. Cambridge, UK: Cambridge University Press, $475 \mathrm{p}$

GIOC, 2003a. Spectral Wave Propagation Model (Oluca-SP). State 
Coastal Office-Spanish Environmental Ministry and University of Cantabria, $170 \mathrm{p}$

GIOC, 2003b. Wave Induced Currents Model in the Surf Zone (CoplaSP). State Coastal Office-Spanish Environmental Ministry and University of Cantabria, 61p.

Gómez, M. and Carretero, J.C., 1997. A two-way nesting procedure for the WAM model: application to the Spanish Coast. Journal of Offshore Mechanics and Arctic Engineering, 119, 20-24.

Gómez-Pujol, L.; Orfila A.; Cañellas, B.; Alvarez-Ellacuria, A.; Mendez, F.; Medina, R., and Tintore, J., 2007. Morphodynamical classification of sandy beaches in a microtidal, low energy marine environment. Marine Geology, 242, 235-246.

González M.; Medina R.; González-Ondina J.; Osorio A.; Méndez F.J., and García, E., 2007. An integrated coastal modelling system for analyzing beach processes and beach restoration projects, SMC. Computers \& Geosciences, 33, 916-931.

Herbers, T.H.C.; Orzech, M.; Elgar, S., and Guza, R.T., 2003. Shoaling transformation of wave frequency-directional spectra. Journal of Geophysical Research, 10(C1), 3013.

Hodur, R.M., 1997. The Naval Research Laboratory's Coupled Ocean/Atmosphere Mesoscale Prediction System (COAMPS). Monthly Weather Review, 125(7), 1414-1430.

Infantes, E.; Terrados, J.; Orfila, A.; Cañellas B., and Alvarez-Ellacuria, A., 2009. Wave energy and the upper depth limit distribution of Posidonia oceanica. Botanica Marina, in press (DOI: 10. 1515/BOT.2009.0XX).

Kirby, J.T., 1986. Rational approximations in the parabolic equation method for water waves. Coastal Engineering, 10, 355-378.

Kirby, J.T. and Dalrymple, R.A. 1983. A parabolic equation for the combined refraction-diffraction of Stokes waves by mildly varying topography. Journal of Fluid Mechanics, 136, 543-566. Komar, P. 1998. Beach Processes and Sedimentation. Englewood Cliffs, New Jersey: Prentice Hall, 338p.
Liu, P.L. and Losada, I.J., 2002. Wave propagation modeling in coastal engineering. Journal of Hydraulic Research, 40(3), 229240.

NOAA (National Oceanographic and Atmospheric Administration). 2008. Rip currents safety. http://www.ripcurrents.noaa.gov (accessed June 4, 2008).

Reniers, A.J.H.M.; Thornton, E.B.; Stanton, T.P., and Roelvink, J.A., 2004. Vertical flow structure during Sandy Duck: observations and modelling. Coastal Engineering, 51, 237-260.

Rusu, E.; Conley, D., and Ferreira-Coelho, E., 2008. A hybrid framework for predicting waves and longshore currents. Journal of $\mathrm{Ma}$ rine Systems, 69(1-2), 74-85.

Smit, M.W.J.; Aarninkhof, S.G.J.; Wijnberg, K.M.; González, M.; Kingston, K.S.; Southgate, H.N.; Ruessink, B.G.; Holman, R.A.; Siegle, E.; Davidson, M., and Medina, R., 2007. The role of video imagery in predicting daily to monthly coastal evolution. Coastal Engineering, 54, 539-553

Soares, C.G.; Carretero, J.C.; Weisse, R., and Alvavarez, E., 2002. A 40 years hindcast of wind, sea-level and waves in European waters. Proceedings of OMAE: 21st International Conference on Offshore Mechanics and Arctic Engineering (Oslo, Norway, OMAE), Paper OMAE 2002-28604.

Undén, P.; Rontu, L.; Järvinen, H.; Lynch, P.; Calvo, J.; Cats, G.; Cuxart, J.; Eerola, K.; Fortelius, C.; Garcia-Moya, J.; Jones, C.; Lenderlink, G.; McDonald, A.; McGrath, R.; Navascues, B.; Nielsen, N.; Odegaard, V.; Rodriguez, E.; Rummukainen, M.; Rõõm, R.; Sattler, K.; Sass, B.; Savijärvi, H.; Schreur, B.; Sigg, R.; The, H., and Tijm, A., 2002. HIRLAM-5 Scientific Documentation. December 2002, HIRLAM-5 Project Report. Norrköping, Sweden: SMHI.

Wright, L.D. and Short, A.D., 1984. Morphodynamic variability of surf zone and beaches: a synthesis. Marine Geology, 56, 93-118.

En este trabajo se presenta un sistema operacional para la predicción de las corrientes generadas por la rotura del oleaje en aguas someras. El sistema se ha desarrollado con el propósito de proporcionar las condiciones de oleaje y corrientes para la seguridad en playas. El sistema está construido en forma modular con cuatro submodelos funcionando de forma autónoma para proporcionar el oleaje y las corrientes dos veces al día con un horizonte predictivo de 36 horas. Las condiciones de oleaje en aguas profundas, se propagan hasta la costa mediante un modelo parabólico de pendiente suave y los tensores de radiación resultantes se introducen como forzamiento en un modelo de Navier Stokes verticalmente integrado. El sistema se ha aplicado en una zona piloto en la Isla de Malloca (Mediterráneo occidental). El sistema ha estado funcionando ininterrumpidamente durante tres años habiéndose mostrado como una herramienta muy válida para la gestión de la seguridad en la playa por parte de las Autoridades. La extensión del sistema a otras áreas del litoral es inmediata una vez se disponga de las batimetrías detalladas de las zonas de interés. 